\title{
HOW GOOD IS THE FOOD SECURITY IN INDONESIA
}

\author{
Lusi Hidayah ${ }^{*}{ }^{\natural}$, Nasikh ${ }^{2}$, Imam Mukhlis ${ }^{2}$ \\ ${ }^{* 1,2}$ Faculty of Economics, State University of Malang, Indonesia
}

DOI: https://doi.org/10.29121/granthaalayah.v8.i7.2020.597

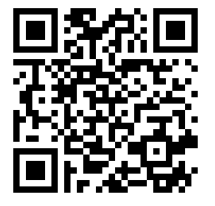

Article Type: Research Article

Article Citation: Lusi Hidayah, Nasikh, and Imam Mukhlis. (2020). HOW GOOD IS THE FOOD SECURITY IN INDONESIA. International Journal of Research GRANTHAALAYAH, 8(7), 308-312. https://doi.org/10.29121/granthaa layah.v8.i7.2020.597

Received Date: 28 June 2020

Accepted Date: 31 July 2020

Keywords:

Food Security

Consumption

Data Panel

Fixed Effect Model

\begin{abstract}
This research aims to provide analysis on the effect of farmers' terms of trade, agricultural land area, gross regional domestic product and population on food security in 34 provinces in Indonesia. The data analysis method used is data panel model with fixed effects model. The results showed that the farmers' terms of trade variable and The agricultural land area had no significant effect on food security in various provinces in Indonesia. Gross regional domestic product variable had significant effect on food security in various provinces in Indonesia. It showed that a high gross regional domestic product variable could decrease the amount of public food expenditure, which means lower consumption incurred for food causes food security to rise. Meanwhile, population variable had positive and significant effect on food security in various provinces in Indonesia, meaning an increase in population also increases the amount of public food consumption. Based on the results, it is recommended to find out how to stimulate various economic sectors in each province in which it could increase the amount of gross domestic product of each region. Better distribution of population could also affect the rate of food security in each province in Indonesia.
\end{abstract}

\section{INTRODUCTION}

Food is the primary source of human needs. Every human being need food, food is the primary basic human needs and its fulfillment is a part of human rights secured in the Constitution of Republic of Indonesia of 1945 [1]. In-depth and sustainable research in the urgency of food security is already feasible to conduct, as the aspects in food security is very multidimensional. In jombang and probolinggo regencies, showing that the commodity in probolinggo between demand and supply is unbalanced, while in jombang, the commodity is only sufficient for its own regency, which calls for a policy on fulfillment of food supply to achieve sustainable food security [2]. From the explanation above, and also in accordance with the instructions in the law number 18 about food, then Indonesia is supposed to be a country with independent food sovereignty. the agricultural problems in China in which China continues to develop into industrial and residential country causes continual increase in the dependency of agricultural product import. This causes a decrease in food security in China as well as a wage gap between farmer households and non-farmer households, ultimately triggering social anxiety [3]. Another thing that also need to be prioritized in providing sources of food production is farmers, as farmers are the main subjects of food provider. an increasing rice farmers' terms of trade would encourage farmers in producing rice. In 2006-2008, the NTP of Rice in West Java and North Sumatera decreased, while it increased in South Sulawesic [4]. Meanwhile agriculture is the

(C) 2020 The Author(s). This is an open access article distributed under the terms of the Creative Commons Attribution License, which permits unrestricted use, distribution, and reproduction in any medium, provided the original author and source are credited. 
dominant economy sector from the entire SAC, and poverty and famine is the most serious problem faced by this region. Agriculture is caught in a low equilibrium trap with low basic productivity, supply shortage, high prices, low return for farmers, and area diversification, causing a threat to food security [5].

Food safety in rural communities is characterized by the economic activity in the agriculture sector based on the local wisdom of the society. In this case, it can be said that farmers and food security have a mutually influencing relationship. The data of food consumption development in Indonesia is depicted in the following figure:

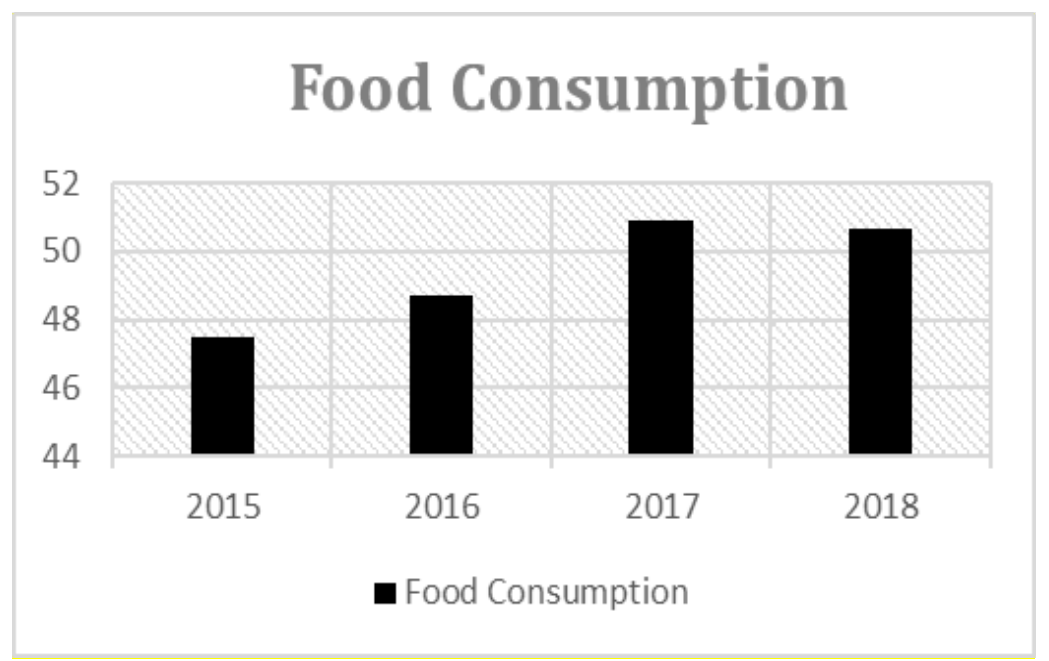

Figure 1: Development of food consumption in Indonesia

Source: BPS, 2018 (processed)

food expenditure towards the total expenditure could be used as an indirect indicator of welfare, while in relation to food security, the share of food expenditure is closely related to various measures of food security, which is the level of consumption. Higher share of food expenditure shows lower food security [6].

\section{MATERIALS AND METHODS}

\subsection{MATERIALS}

The Preamble of the 1945 Constitution of The Republic of Indonesia mandated that the purpose of the independence of Indonesia is to achieve social justice and prosperity of the people [7]. One of the important elements in fulfilling the prosperity of the people is sovereignty and independence in food availability. Food is the primary mandatory needs for human to live. Food is all things derived from the biological source of agricultural, plantations, forestry, fisheries, livestock, waters, and water products, whether processed or unprocessed that is allocated as food or drink for human consumption, including food additives, raw food materials, and other materials used in the preparation, processing, and/or manufacture of food or beverages [1].

Maslow's theory, which stated that humans are motivated to fulfill their needs. Those needs are separated into several levels, from physiological needs like food as the lowest to self-actualization as the highest. Food security is related with consumption pattern in terms of the share in food expenses. Engel's law stated that if there is no change in taste, then the percentage of food expenses will decrease as the income raises. This is a generalization that associates the share of food expenses with income [8].

\subsection{METHODS}

The research object of this study was taken from provinces in Indonesia, consisting of 34 regencies from 2015 to 2018. The data used are secondary data, such as; Food Consumption (Percent), Farmers' Terms of Trade, Agricultural Land (Ha), Gross Regional Domestic Product (billion), population (thousand). The data is obtained from various data sources, such as; Central Bureau of Statistics (BPS) and Food Security Service (DKP) , based on chow test model, showed that the probability value is less than alpha, and from the result of the hausman test showed that 
the probability is also less than alpha, then the appropriate model is fixed effect model. The result of the normality test showed that the probability is about 0.27 , which is higher than the alpha (0.5), so the residual is normal distribution. Then, followed by multicollinearity test which indicated that the correlation value between independent variables is less than 0.8 , it can be said that multicollinearity did not occur in the data. For nonheteroscedasticity test which indicated that the probability is greater than 0.5 , it can be concluded that heteroscedasticity did not occur. For non-autocorrelation test, the result from durbin watson table indicated greater value, meaning that this test complies.

for fixed effect model is:

$$
y=(\alpha i t+u i)+X \text { 'itu } \beta+V \text { itu }
$$

Where $\mathrm{Y}$ is the dependent variable, $\mathrm{X}$ is the independent variable and $\varepsilon$ is the term of error. The notation $\mathrm{i}$ indicates the distribution of the observed unit, $t$ indicates the observation period, $\alpha$ indicates the magnitude of the constant and notation $\beta$ indicates the number of free variable coefficient [9]

Meanwhile, the fixed effect model is:

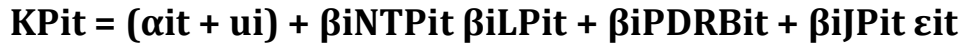

Where KP is Food Security (Food Consumption), NTP is Farmers' Terms of Trade, LP is Agricultural Land, PDRB is Gross Regional Domestic Product and JP is Population.

\section{RESULTS AND DISCUSSIONS}

The result of data processing using fixed effect model on the data panel can be written as follows:

$$
\mathrm{KP}=\text { 1.768.524 + 0.086095NTPit - 0.000000823LPit - 0.000131PDRBit + 0,002360JPit + v it }
$$

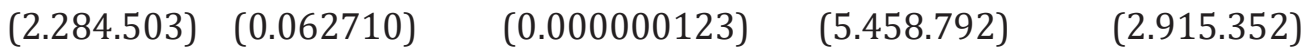

The numbers in the bracket show the value of $t$ count. Adjusted R-Squared of 0.93, the Durbin Watson's Statistic is about 2,646,469 and F-Statistic of about 3,545,701. The estimation result above indicates that PDRB and Population variables significantly affect food security in every Provinces in Indonesia, while NTP and Agricultural Land variables do not significantly affect food security in every Provinces in Indonesia.

From 33 provinces, as many as 22 provinces experienced a decrease in NTP and 11 provinces experienced an increase in NTP. The greatest decrease in NTP was in 2018 in the Riau Province, which was about 11.63 percent, Meanwhile, West Nusa Tenggara was the province with the greatest NTP increase of 3.20 percent. Overall, the rainbow exchange rate decreases every year. It can be shown in the following figure:

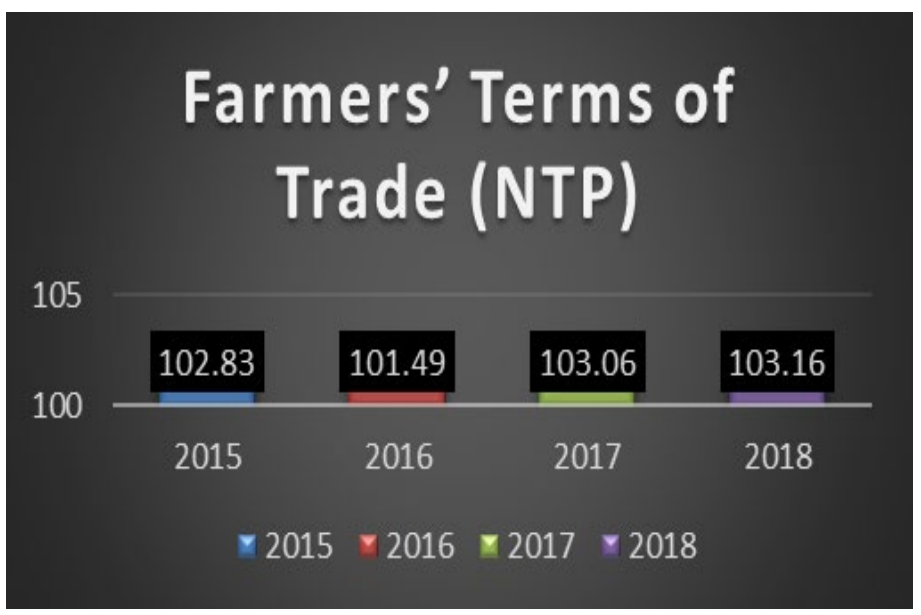

Figure 2: Development of Farmers' Terms of Trade in Indonesia

Source: BPS, 2018 (processed) 
NTP has significant effect towards farmers' passion in performing agricultural activities, and that also affect the food supply which will be consumed by the people. Food reserves (food availability), one of the indicators of food security according to GSFI (Global Security Food Index) should also be paid attention to. If NTP continues to drop, it is feared that it will affect food reserves, and its effect could worsen the condition of food security in Indonesia [10]

Referring to the laws of food which stated that Indonesia should be a country with food sovereignty. Therefore, in addressing this issue, the government should clearly pay attention to the solving point. The agricultural land area development trend in Indonesia also declines, based on the research result, agricultural land negatively affects food security. If agricultural land declines, then food consumption will rise. the agricultural problems in China in which China continues to develop into industrial and residential country causes continual increase in the dependency of agricultural product import. This causes a decrease of food security in China [3]. The significant effect of population on food security shows that population is an important instrument in determining the rate of food security in various provinces in Indonesia, accordance with the theory by Malthus (1998), which stated that food growth such as arithmetical count and population growth such as geometrical progression, shows that as the population growth increases, then food needs also increases. Therefore, population and its distribution also affect food security. The connection between population and its distribution can be seen to describe food distribution in an area and how the food is distributed. the greatly dynamic condition of the population surely affects the condition of food security in a certain area and vice versa. The quantity of population in both provinces have significant effects on the condition of food utilization and accessibility. Until 2035, West Java will face food insecurity, while East Java will face food security. Besides population variable, Gross Regional Domestic Products variable also has significant effect,

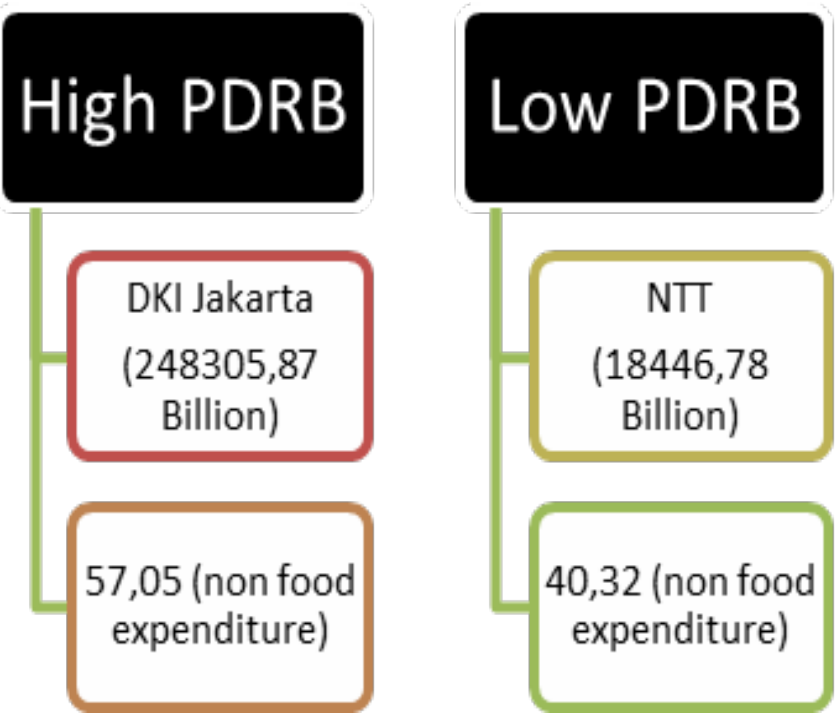

Figure 4: Comparison of Gross Regional Domestic Products on food security (Food Consumption) Source: BPS, 2018 (processed)

This is also closely related to Engel's Law which stated that if there is no difference in taste, then the percentage of expenditure for food will decrease as income increases If the Gross Regional Domestic Products in each province in Indonesia increases, then it could also help increasing food security in that area.

Based on the research results, it can be concluded that to increase the value of Economic Growth in each provinces in Indonesia, in this case to increase the food security in that area, the highest PDRB is in DKI Jakarta, and it is in line with the food security in DKI Jakarta, whereas the food expenditure in 2018 is about 57.05\%, while the lowest PDRB is in East Nusa Tenggara, which is around 18446,78 billion Rupiah in 2018. In terms of food security, East Nusa Tenggara shows a decrease, in which the food security continues to drop each year. It is shown by the high food expenditure of about $59.68 \%$, whereby East Nusa Tenggara is the province with the lowest food security than the other provinces in Indonesia [6]. In this case, the problem is how to increase the income in order to reinforce food security in every province in Indonesia. 


\section{CONCLUSIONS AND RECOMMENDATIONS}

The research results conclude that Farmers' Terms of Trade (NTP) and Agricultural land area does not significantly affect food security in each province in Indonesia. Moreover, Gross Regional Domestic Products (PDRB) has negative and significant effect, while population has positive and significant effect on food security in each province in Indonesia, it can be said that as the income of the society increases, then the expenditure of food consumption will decrease and vice versa. In this case, the consideration is how to stimulate economic growth in an area to increase the condition of food security. Moreover, population has positive and significant effect, in accordance with the theory of Malthus (1998) which stated that food growth such as arithmetical count and population growth such as geometrical progression, shows that as the population growth increases, then food needs also increases. In addition, population could also describe the food distribution in an area and how it is distributed. If there is a lot of population and the food security is insecure, it causes a concern of malnutrition, while the Laws of Food stated that every citizen has the right to have access to proper food. The government also has the obligation to ensure that.

\section{SOURCES OF FUNDING}

This research received no specific grant from any funding agency in the public, commercial, or not-for-profit sectors.

\section{CONFLICT OF INTEREST}

The author have declared that no competing interests exist.

\section{ACKNOWLEDGMENT}

None.

\section{REFERENCES}

[1] The Constitution of The Republic of Indonesia of 1945, Law Number 18 of 2012.

[2] Nasikh. 2018. An Analysis of the Local Resources Potential to Achieve Food Security in Jombang and Probolinggo Regencies East Java Indonesia. Iran. Econ. Rev. Vol. 22, No. 2, 2018. pp. 135-148.

[3] Anderson kym dan Anna Strutt. 2014. Food Security Policy Options for China: Lesson From Other Countries. Food Policy 49:50-58

[4] Tjetjep Nurasa dan Muchjidin Rachmat. 2013. Rice Farmers Term of Trade Analysis Some Paddy Producing Areas in Indonesia. Agro Economy Journal. Volume 31 No. 2, October 2013: 161-179.

[5] Shrikant K. Kalamkar .2011. Food Security in South Asia with Special Reference to India. Sage Publication

[6] Central Bureau of Statistics (BPS).2018. Calorie and Protein Consumption of the People of Indonesia and Its Provinces. BPS.Jakarta

[7] The Constitution of The Republic of Indonesia of 1945

[8] Wulandari, Inda. 2013. Determining Factor of Household Food Security in East Nusa Tenggara [Thesis]. Bogor: Graduate School, IPB University

[9] Mukhlis, Imam. Simanjuntak, Timbul Hanomangan. 2016. The Nexus of Economic Factors and Poverty in the Region's Economy. International Journal of Management Sciences Vol. 7, No. 1, 2016, 14-20

[10] Central Bureau of Statistics (BPS).2018. National Social Economy Survey (SUSENAS). BPS. Jakarta 